\title{
Evaluation of pre-tightening in abutments and prosthetic screws on different implant connections
}

\author{
Avaliação do pré-aparafusamento em pilares e parafusos \\ protéticos em diferentes conexões de implante
}

\begin{abstract}
Purpose: This study evaluated pre-tightening maintenance in abutment and prosthetic screws of external and internal hexagon implant with straight and angled abutments.

Methods: Four groups of implants and abutments were assessed combining internal and external hexagon and straight and angled abutments, which were retained by titanium screws tightened to $20 \mathrm{~N} . \mathrm{cm}$. Crowns were retained with gold screws tightened at $10 \mathrm{~N} . \mathrm{cm}$. A vertical line was ascribed across the implant-abutment-crown interface to verify horizontal displacement by a light microscope. The fatigue tests were performed in a servo-hydraulic machine, which delivered forces between 100 and $120 \mathrm{~N}$ for 250,000 cycles. The screw was removed, and the detorque value was recorded. Data were analyzed with 2-way ANOVA and Tukey's test.

Results: No horizontal displacement was observed on the interface of implant-abutment or abutment and crown. It was found significant difference for prosthetic screw between implant connection types, but without interaction with abutment. However, for abutment screw, there was a difference between implant connection types and abutment with interaction between implant and abutments. The straight abutment showed significant better performance than the $17^{\circ}$ angled abutment.

Conclusion: The connection implant types or abutment affected pre-tightening maintenance. Internal and external hexed connections were effective to avoid horizontal displacement of crowns.
\end{abstract}

Key words: Angled abutments; fatigue testing; implant dentistry; implant connection

\section{Resumo}

Objetivo: Este estudo avaliou a manutenção do pré-aparafusamento em pilar e parafuso protético de implantes com hexágono interno e externo, com pilares retos e angulados.

Metodologia: Quatro grupos de implantes e pilares foram avaliados, combinando-se o hexágono interno ou externo e o pilar reto ou angulado, os quais foram retidos por parafusos de titânio aparafusados $20 \mathrm{~N} . \mathrm{cm}$. As coroas fora retidas com parafusos de ouro aparafusados a $10 \mathrm{~N} . \mathrm{cm}$. Uma linha vertical foi delineada sobre a interface implante-pilar-coroa para verificar o deslocamento vertical com uso de microscópio ótico. Os testes de fadiga foram realizados em uma máquina servo-hidráulica, que promoveu forças entre 100 e $120 \mathrm{~N}$ por 250.000 ciclos. O parafuso foi removido e o valor de detorque for registrado. Os dados foram analisados por ANOVA de dois fatores e teste de Tukey.

Resultados: Nenhum deslocamento horizontal foi observado na interface implante-pilar ou pilar-coroa. Observou-se uma diferença significativa para o parafuso protético entre os tipos de conexão do implante, mas sem interação com o pilar. Porém, para o parafuso do pilar houve diferença entre tipos de conexão e pilar, com interação entre pilar e implante. $\bigcirc$ pilar reto mostrou melhor performance que o pilar angulado a $17^{\circ}$.

Conclusão: Os tipos de conexão do implante ou pilar afetaram a manutenção do préaparafusamento. As conexões de hexágono interno e externo foram efetivas para evitar o deslocamento horizontal das coroas.

Palavras-chave: Pilar angulado; teste de fadiga; implantodontia; conexão do implante

\author{
Leonardo Panza a \\ Noeli Boscatto ${ }^{b}$ \\ Altair Antoninha Del Bel Cury a
}

a Piracicaba Dental School, State University of Campinas, Piracicaba, SP, Brazil

${ }^{b}$ Dental School, Federal University of Pelotas, Pelotas, RS, Brazil

\author{
Correspondence: \\ Altair A. Del Bel Cury \\ Faculty of Dentistry of Piracicaba \\ Av. Limeira, 901 - Caixa Postal 52 \\ Piracicaba, SP - Brazil \\ $13414-903$ \\ E-mail:altcury@fop.unicamp.br
}

Received: March 29, 2010

Accepted: May 31, 2010

Conflict of Interest Statement: The authors state that there are no financial and personal conflicts of interest that could have inappropriately influenced their work.

Copyright: (c) 2010 Panza et al.; licensee EDIPUCRS. This is an Open Access article distributed under the terms of the Creative Commons AttributionNoncommercial-No Derivative Works 3.0 Unported License. 


\section{Introduction}

Despite the successful clinical outcomes of Brånemark (1), some problems in implant therapy are still considered insurmountable. Studies have shown that after osseointegration failures, screw loosing, or fracture of its abutment screws and prosthetic retaining screw are still considered the most important problems and can affect the success of implant restorations (2). Furthermore, mechanical failures have been associated with screw joint instability between the abutment and the implant (3). In addition, the influence of implantabutments joint in screw loosing or fracture is controversial (4). Regarding implants connection type, Goodacre et al. (5) and Balfour and $\mathrm{O}^{\prime}$ Brien (6) reported best results when internal hexagon design implants were used, while Khraisat et al. (7) considered that external hexagon implant system reduces the problem of screw loosening or fracture. On the other hand, Breeding et al. (8) reported failure due to biomechanics problems when either internal or external hexagon implant systems were used.

Besides the problem with the implant connection system, the use of angled abutments is also related to screw loosing or fracture due to the fact that occlusal forces are not directed along the implant axis (9). However, the angled abutment is very useful, considering the anatomy of the jaw and the morphology of the residual ridge, which is a determining factor in the orientation and angulations in which the implants should be placed. When a difference is found between the long axis of the inserted implant and the long axis of the planned tooth, an angled abutment should be used to restore functional and esthetic aspects (9). Moreover, implant manufactures have recognized that screw loosing is a significant problem. Thus, either internal or external hexagon was incorporated in implants to stabilize the screw joint. Even though these antirotational design characteristics were incorporated into the implant system, machining tolerances still allow a small amount of movement between the abutment and implant, and the clamping action of the screw should prevent this movement (10).

Although there are many studies about joint screw failures, the effect of angled abutments in the maintenance of stability of the screw joint, as well as the influence of implants connection type in screw joint failures, remains a concern. Thus, this study evaluated the pre-tightening maintenance of titanium abutment screw and gold prosthetic screw using internal and external hexagon implants and straight and $17^{\circ}$ angled abutment, after a simulated cycling load. The horizontal displacement between implant-abutment and abutment-crown interface was also recorded.

\section{Methods}

Forty set of implants, abutments, titanium screws, acrylic resin crowns and gold screws (Conexão, Sistemas de Próteses, São Paulo, Brazil) were divided into 4 groups of 10 assemblies each: (G1) implant with an internal hexagon (Conect $\mathrm{AR}^{\circledR}$ ) and straight Estheticone ${ }^{\circledR}$ abutment; (G2) implant with an internal hexagon (Conect $4 \mathrm{AR}^{\circledR}$ ) and $17^{\circ}$ angled Estheticone ${ }^{\circledR}$ abutment; (G3) implants with an external hexagon and straight Estheticone ${ }^{\circledR}$ abutment; (G4) implant with external hexagon and $17^{\circ}$ angled Estheticone ${ }^{\circledR}$ abutment. All implants were $3.75 \mathrm{~mm}$ of platform and $10 \mathrm{~mm}$ in length. Each implant was embedded to the level of collar in a polyester resin block (22 $\mathrm{mm}$ of diameter), using a surveyor guide (Bioart, 1000 N, São Paulo, Brazil) so that the tip of the stylus would contact the acrylic resin crown on each sample to the center of the abutment. Standardized acrylic resin crowns were fabricated for each assembly. A metallic master model simulating a human pre-molar was duplicate using a elastomeric material (Elite Double 8, Zhermack, Italy), and the crowns were made using self polymerized acrylic resin (Classico Artigos Odontológicos Ltd, São Paulo, Brazil) over the implant components. After $24 \mathrm{~h}$, each abutment screw of the test groups was tightened to a torque of $20 \mathrm{~N} . \mathrm{cm}$. After 10 minutes, the abutment screw was again tightened to 20 N.cm. Then, the crown was positioned, and each prosthetic gold screw was tightened by applying a 10 N.cm. A torque controller device (Lutron Eletronics TM 800, Taipei, Taiwan) was used to ensure that an accurate and reproducible strength was applied to each abutment or prosthetic screw. Furthermore, each implant was rigidly held in a special holding device during screw tightening to ensure rigid fixation without rotation during the tightening. Following this procedure a vertical line was scribed using a bur across the implant-abutment and abutment-crown interface to evaluate horizontal displacement (3).

The specimens were placed in a cyclic loading machine with 10 piston heads activated by an air compressor (ERFOP 10, Erios, São Paulo, Brazil), at $37^{\circ} \mathrm{C}$ of temperature assured by means a distilled water bath. The dynamic load was applied in a $2 \mathrm{~mm}$ square area to the occlusal fossa of each crown by a unidirectional vertical piston calibrated under displacement control, cycling between 100 and $120 \mathrm{~N}$. Cycling loading continued for 250,000 cycles, simulating a 3-month period of in vivo mastication approximately $(3,11)$.

After the test completion, each specimen was removed from the mechanical fatigue machine and microscopically inspected for horizontal displacement in a tri-dimensional digital measurement microscope (Walter Uhl, Asslar, Germany). The observation was performed three times by sample by one single operator. The images were captured and analyzed by appropriate software (VideoCap 32, Microsoft, USA). Specimens were then replaced in the rigid holding device to ensure rigid fixation without rotation for detorque of the screws. The electronic controller device was carefully maintained in the long axis of the implant with the driver seated in the screw head. Abutment and prosthetic screws were removed, and detorque values were recorded in N.cm. After this procedure, screw and abutment surfaces were examined to verify any fracture occurrences.

The statistical analysis was performed using the SAS/LAB package (SAS software, version 8.01, SAS Institute Inc., Cary, NC, USA), with alpha fixed at $5 \%$. The normality of errors distribution and the degree of non-constant variance 
were checked for each response variable. The two-way ANOVA was used to test the null hypothesis of no difference between implant connection types and detorque of screws either abutment or prosthetic screws. The Tukey's test was then used for post-hoc ANOVA comparisons.

\section{Results}

The results are presented in tables 1,2 and 3. The interface between implant-abutment and abutment-crown showed no displacement when the vertical lines were observed.

The detorque values for prosthetic screws regarding the connection implant types (internal and external hexagon), showed significant differences by the two-way ANOVA $(P<0.0001)$, but without interaction with the abutment types (Table 1).

Abutment screw detorque was affected by the connection implant types and by abutment type (straight or angled) $(P<0.001)$ (Table 2). The $17^{\circ}$ degree angled abutment showed the higher values for detorque independently from implant connection types $(P<0.001)$ (Table 3$)$.

Table 1. Results of the 2-way ANOVA for prosthetic screw detorque.

\begin{tabular}{lcrrrc}
\hline \multicolumn{1}{c}{ Source } & df & \multicolumn{1}{c}{ SS } & \multicolumn{1}{c}{ MS } & \multicolumn{1}{c}{ F } & \multicolumn{1}{c}{$\boldsymbol{P}$} \\
\hline Implant & 1 & 14.02 & 14.02 & 22.35 & $<.0001$ \\
Abutment type & 1 & 0.09 & 0.09 & 0.15 & 0.6978 \\
Implant x abutment & 1 & 0.05 & 0.05 & 0.08 & 0.7828 \\
\hline
\end{tabular}

Table 2. Results of the 2-way ANOVA for abutment screw detorque.

\begin{tabular}{lccccc}
\hline \multicolumn{1}{c}{ Source } & df & SS & MS & F & $P$ \\
\hline Implant & 1 & 0.63 & 0.63 & 0.05 & 0.8189 \\
Abutment & 1 & 950.06 & 950.06 & 80.58 & $<0.001$ \\
Implant x abutment & 1 & 144.33 & 144.33 & 12.24 & $<0.0013$ \\
\hline
\end{tabular}

Table 3. Detorque values $(\mathrm{N} / \mathrm{cm})$ in abutment screw after fatigue test. (Mean \pm SD).

\begin{tabular}{lcc}
\hline \multicolumn{1}{c}{ Implant connection type } & $\begin{array}{c}\text { Straight } \\
\text { abutment }\end{array}$ & $\begin{array}{c}17^{\circ} \text { Angled } \\
\text { abutment }\end{array}$ \\
\hline Internal hexagon & $5.6 \pm 1.1 \mathrm{Aa}$ & $7.7 \pm 0.9 \mathrm{Ab}$ \\
External hexagon & $4.0 \pm 1.8 \mathrm{Ba}$ & $8.7 \pm 1.1 \mathrm{Bb}$ \\
\hline
\end{tabular}

Capital letters denote difference between implants and lower case letters between abutments types (Tukey's test, $P<0.05$ ).

\section{Discussion}

The pre-tightening and the contacting areas of implant and abutment also influence the stability of implant - abutment connection and propensity for screw loosing. Tightening the screw creates the tension in the screw necessary to keep the components together. (12). Moreover, the resistance to avoid losing screw is related to the joint preload (13). Thus, the greater the joint preload, the greater the resistance.

In the present study, it was not observed displacement in the interfaces of implant-abutment or abutment-crown. Internal and external hexagon connections were effective to avoid rotation displacement. This result is consistent with the findings of Cibirka et al. (3). Regarding the implant connection types and prosthetic screw, no interaction was found and no screw was lost. These findings could be explained by the fact that prosthetic screw preload was kept, considering that screw loosing occurs when the clamping force developed within the assembly is less than the forces, which pull the assembly apart (14).

Although statistically significant differences were found between the implant connection types and abutment types regarding detorque abutment screw, the results do not allow to assert whether internal hexagon implant is better than external hexagon in the maintenance of screw joint stability. The abutment screws detorque of the straight abutment showed better results when internal hexagon was used; conversely, the angled abutments exhibited the higher detorque values for external hexagon. As preload can be influenced by component and screw materials $(15,16)$, torque delivery system (17), manufacturer quality control $(16,23)$, screw joint design (18), surface roughness (19), and fatigue testing $(3,12)$ is very difficult to attribute the results to only one of these causes. Moreover, Binon (4), in his study about implant-abutment misfit on screw joint stability, concluded that the presence of the external implant hexagon increased the resistance to screw loosing. In addition, Cibirka et al. (3) suggested that a less precise fit in the width of the hexagon space, or its total elimination, did not adversely affect the preload after fatigue testing (3).

The better results found when angled abutment was used could be assessed by a microscopically analysis of the relationship between abutment screw and internal implant threads. The distribution of the torque to the system depends on fitting between the screw head and abutment platform, through friction between screw head and abutment and friction between the threads on the screw and implant; and the tension within the screw, defined as the preload (18). This condition probably could be better in angled abutment in comparison with straight abutment.

The lack of loosing screw observed in this study can be related to factors such as the amount of load applied, even it was applied the load suggested by the manufacturer, the location and direction of force application and the number of cycles applied during the fatigue test. It is important to considerer that although the load is arbitrary, the test attempted to simulate the clinical conditions. The number of loading cycles used could be insufficient to cause screw joint deterioration as suggested by Bickford et al. (19). This consideration is in agreement with the study by Binon and Mc Hugh (20), who concluded that joint failure did not occur until of 5 million cycles for abutment screws tightened to $30 \mathrm{~N} . \mathrm{cm}$, whereas $20 \mathrm{~N} . \mathrm{cm}$ 
of torque allowed failure to occur at 357,162 cycles; in the present study only 250,000 cycles were used. In addition, it was suggested that abutments tightened with 20 N.cm are expected to fail due to screw loosing in 2 to 3 months (10).

Even though no screw loosing or damaged screw from either abutment or prosthetic crown was found in this study, the $17^{\circ}$ angled abutment had better performance than the straight abutment. New investigations on the influence of angled abutment in the maintenance of pre-tightening load should be conducted.

\section{Conclusions}

Within the limitations of this study, it could be concluded that the dynamics in maintenance of pre-tightening was influenced by the connection between implant and abutment and by the abutment types (straight or angled).

\section{Acknowledgments}

This study was partially supported by FAPESP (Process 04/04911-4).

\section{References}

1. Branemark PI, Zarb G, Albrektsson T. Tissue-integrated prostheses: osseointegration in clinical dentistry. Special Edition for Nobelpharma. Chicago: Quintessence; 1987.

2. Cho SC, Small PN, Elian N, Tarnow D. Screw loosening for standard and wide diameter implants in partially edentulous cases: 3 to 7 year longitudinal data. Implant Dent 2004; 13:245-50

3. Cibirka RM, Nelson, SK, Lang, BR, Rueggeberg FA. Examination of the implant-abutment interface after fatigue testing. J Prosthet Dent $2001 ; 85: 268-75$

4. Binon PP. Evaluation of machining accuracy and consistency of selected implants, standard abutments and laboratory analogs. Int J Prosthodont 1996;8:162-78.

5. Goodacre CJ, Kan JYK, Rungcharassaeng K Clinical complications of osseointegrated implants. J Prosthet Dent 1999;81: 537-52.

6. Balfour A, $\mathrm{O}^{\prime}$ Brien GR. Comparative study of antirotational single tooth abutments. J Prosthet Dent 1995;73:36-43.

7. Khraisat A, Abu-Hammad O, Dar-Odeh N, Al-Kayed AM. Abutment screw loosening and bending resistance of external hexagon implant system after lateral cyclic loading. Clin Implant Dent Relat Res $2004 ; 6: 157-64$

8. Breeding LC, Dixon D, Nelson EW, Tietge JD. Torque rotational to loosen single-tooth implant abutment screws before and after simulated function. Int J Prosthodont 1993;6:435-9.

9. Sethi A, Kaus T, Sochor P, Axmann-Krcmar D, Chanavaz M. Evolution of the concept of angulated abutments in implant dentistry: 14-year clinical data. Implant Dent 2002;1 1:41-50.
10. Dixon DL, Breeding LC, Sadler JP, Comparison of screw loosing, rotation and deflection among three implant designs. J Prosthet Dent 1995;74:270-8.

11. Gibbs CH, Mahan PE, Mauderli A, Lundeen HC, Wals EK. Limits of human bite strength. J Prosthet Dent 1986;56:226-9.

12. Kano SC, Binon P, Bonfante G, Curtis DA. Effect of casting procedures on screw loosening in UCLA type abutments. J Prosthodont 2006; 15:77-81.

13. Binon PP. Implants and components: entering the new millennium. Int J Oral Maxillofac Implants 2000;15:76-94.

14. Byrne D, Jacobs S, O' Connel B, Houston F, Claffey N. Preloads generated with repeated tightening in three types of screws used in dental implant assemblies. J Prosthodont 2006;15:164-71.

15. Tan KB, Nicholls JI. Effect of 3 torque delivery systems on gold srew preload at the gold cylinder-abutment screw joint. Int J Oral Maxillofac Implants 2002;17:175-83.

16. Tan KB, Nicholls JI. Implant- abutment screw joint preload of 7 hex-top abutment systems. Int J Oral Maxillofac Implants 2001 ; 16:367-77.

17. Schulte JK, Coffey J. Comparison of screw retention of nine abutment systems. A pilot study. Implant Dent 1997;6:28-31.

18. Shigley JE. Mechanical engineering design. 6.ed. New York: McGraw Hill, 1977.

19. Bickford JH. An introduction the design and behavior of bolted joints. New York: M. Dekker;1981

20. Binon PP, Mc Hugh MJ MJ. The effect of eliminating implant/ abutment rotational misfit on screw joint stability. Int J Prosthodont $1996 ; 9: 511-9$. 